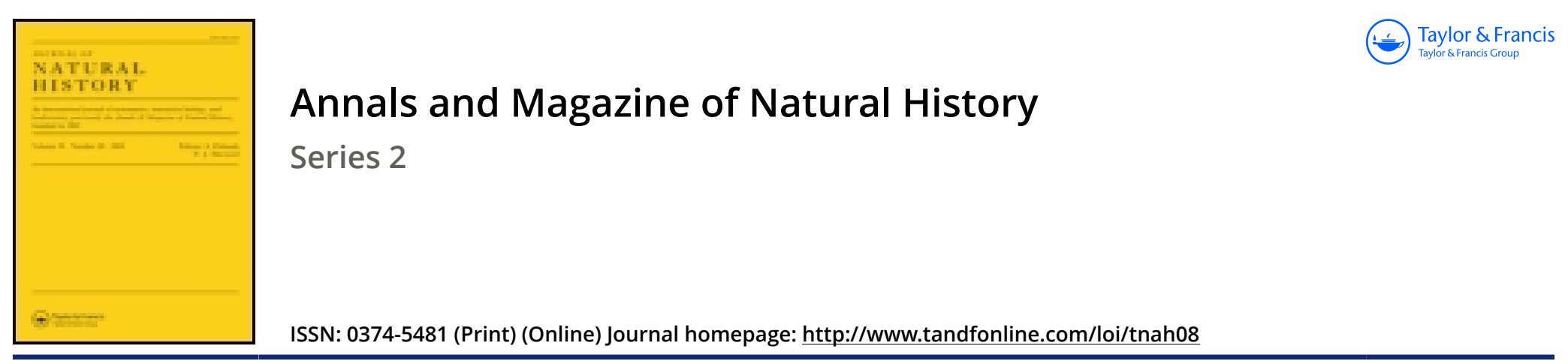

\title{
On the velvet-like periostraca of Trigona
}

\section{J.E. Gray Esq.}

To cite this article:J.E. Gray Esq. (1849) On the velvet-like periostraca of Trigona, Annals and Magazine of Natural History, 4:22, 296-297, DOI: 10.1080/03745486009494833

To link to this article: http://dx.doi.org/10.1080/03745486009494833

$$
\text { 曲 Published online: } 17 \text { Dec } 2009 .
$$

Submit your article to this journal ๔

\footnotetext{
Q View related articles $\longleftarrow$
} 


\section{Measurements of the Trunk of the Aurochs.}

Length of vertebral column from the atlas to the sixth caudal vertebra, measured across the diapophyses $\ldots \ldots \ldots .81$

Length of vertebral column over the neural spines $\ldots \ldots 88$

Length of cervical region over the diapophyses ........ 17

Length of dorsal region ditto ............. 30

Length of lumbar region ditto $\ldots \ldots \ldots \ldots \ldots \ldots \ldots \ldots 13$

Length of sacral and six caudal ditto $\ldots \ldots \ldots \ldots \ldots \ldots 21$

Depth of spine of seventh cervical . . . . . . . . . 8

Depth of spine of first, second and third dorsal, being the three longest, each $\ldots \ldots \ldots \ldots \ldots \ldots \ldots \ldots \ldots \ldots \ldots 11$

Length of first rib $\ldots \ldots \ldots \ldots \ldots \ldots \ldots \ldots \ldots \ldots$

Length of ninth, or the longest ............. 18 $\frac{1}{2}$

Seven ribs articulate by separate hæmapophyses to the sternum.

Length of diapophysis of fourth lumbar, or the longest .. $4 \frac{\mathrm{r}}{2}$

Breadth of atlas across the neural arch .......... 7

Extreme breadth across the spines of the ilia $\ldots \ldots \ldots \ldots 14$

Extreme breadth across the pubis, from the inner edge of each acetabulum ................... 6

\section{MISCELLANEOUS.}

On the Velvet-like Periostraca of Trigona. By J. E. GRAY, Esq.

In my account of the species of the genus Trigona of Megerle, I mentioned that several species were covered with a velvet-like silvery coat hiding the surface of the horny periostraca.

When this coat is minutely examined, it is found to be formed of numerous elongated spicula of a uniform length placed side by side perpendicular to the surface of the periostraca, so as to form a pile like velvet or plush. The length of the spicula, and consequently the thickness of the coat, increases towards the margin of the shell. This coat is generally rubbed off from the more convex part of the specimens which have not been very carefully preserved, but in such examples it is usually to be found near the edge of the valves, or on the lunule and other sunken portions of the surface.

The Rev. Dr. Fleming has lately drawn my attention to the fact, that these spicula are siliceous and similar to those of siliceous sponges ; indeed Dr. Fleming is inclined to regard the velvet-like coat as a species of Halichondria parasitic on the shell rather than as a portion of the periostraca itself; and Dr. George Johnson of Berwick, who examined Dr. Fleming's specimen with me, is inclined to take the same view of the question.

With these authorities opposed to my view I have reconsidered the question, but I am still inclined to believe that I am correct in considering the spicula as part of the shell formed by the animal as it produces the periostraca on the edge of the shell, and offer the following reasons in support of this conclusion :-

Ist. This kind of coat is found on several species of the genus which inhabit different parts of the world. 
2nd. That the coat is uniformly spread over the whole surface of the shell; in all parts of the shell it is only formed of a single series of spicula placed side by side parallel to each other and perpendicular to the surface of the shell, and that the spicula gradually increase in length, and consequently the coat in thickness, as the shell increases in size and thickness.

3rd. That this velvet-like coat bears no resemblance to any specimens of sponge that have come under my examination; the spicula are not interwoven or felted together, but are placed parallel to each other in a most uniform manner; and the coat always presents a uniform and even surface, and never shows any inclination to form prominences or branches on the surface, which is the habit of all the sponges I have seen which envelope and are parasitic on shells or other marine animals.

4th. Our previous knowledge of the aeconomy of Mollusca has prepared us to believe that they can secrete siliceous bodies and form appendages on the surface of the periostraca separate from the body of the shell. Mr. Hancock has shown that the teeth on the tongue of various Gasteropodous Mollusca are siliceous, and he has shown that the surface of the foot and of various parts of the mantle of different acephalous and gasteropodous Mollusca is studded with siliceous granules, by which these animals are enabled to rasp away the surface of different marine bodies.

Well-preserved specimens of Lucina pennsylvanica have each of the concentric ridges which ornament the surface of the shell fringed with a membranaceous or semicartilaginous expansion, which is edged with a series of most beautiful, regular, thick, convex, pearllike pieces of shell, and the concentric ridges which cross the whorls of the outer surface of the horny operculum of Liopa (Delphinula, sp. Lam.) are fringed with beautiful regular subglobular pieces of shell.

I may further observe, that the outer surface of the periostraca of many shells, both univalve and bivalve, is often covered with short crowded hair-like processes forming a velvety outer coat, as is easily seen in various species of Pectunculus, Buccinum, Triton, \&c.

I arn therefore inclined to believe that in these Trigone every layer or line of periostraca which is added to the edge of the one before deposited is furnished with a series of erect siliceous spicula, which, in conjunction with those previously deposited, form the velvet-like coat of the periostraca found in that genus of bivalve shells.

Though I am not willing to adopt the views of my friends Drs. Fleming and Johnson, yet $I$ think that the discovery of the velvetlike coat of the Trigona being formed of siliceous spicula, is a most interesting addition to our knowledge of the occnomy of Mollusca.

$$
\text { THE TORTOISE-SHELL OF CELEBES*. }
$$

Amongst the more valuable of the commodities which the enterprising and industrious Bugis annually bring to us from Celebes and

* Translated from the 'Verhandelingen van het Bataviaash Genootschap van Kunsten en Wetenschappen,' vol. xvii. p. i.

Ann. \& Mag. N. Hist. Ser. 2. Vol. iv. 